\title{
Influence of Environmental Factors on Rhinosinusal Tumours
}

\author{
RAZVAN HAINAROSIE ${ }^{1}$, EUGENIA MARIA DOMUTA2*, MIHAIL TUSALIU1*, MARIUS GABRIEL DABIJ A3*, FLORIN ANGHELINA*, \\ DOINEL RADEANU5\#, OCTAVIAN DRAGOS PALADE ${ }^{6 \#}$ \\ ${ }^{1}$ Carol Davila University of Medicine and Pharmacy, $8^{\text {th }}$ Eroii Sanitari Blvd., 050474, Bucharest, Romania \\ ZUniversity of Medicine and Pharmacy, Otorhinolaryngology Discipline, Oradea, Romania \\ ${ }^{3}$ Grigore T. Popa University of Medicine and Pharmacy, Neurosurgery Discipline, 16 Universitatii Str., 700115, Iasi, Romania \\ 4 University of Medicine and Pharmacy, Otorhinolaryngology Discipline, 2 Petru Rares Str., Craiova, Romania \\ 5 Iuliu Hateganu University of Medicine and Pharmacy, Otorhinolaryngology Department, Cluj-Napoca, Romania \\ ${ }^{6}$ Grigore T. Popa University of Medicine and Pharmacy, Otorhinolaryngology Discipline, Second Surgery Department, 16 Universitatii \\ Str., 700115, Iasi, Romania
}

\begin{abstract}
Cancer of the nasal cavity and paranasal sinuses is a rare malignancy. The tumours of the nasal cavity are thus associated with the maxillary and ethmoidal sinuses. Those that start from the nasal vestibule and nasal septum raise particular problems and, although rare, form a particular group of cases among the rhinosinusal tumours. Radiation exposure, viral infections and constitutional factors were associated with the occurrence of rhinosinusal neoplasia also, but the evidence is inconclusive and indicates that only a small proportion of all squamous carcinomas can be attributed. The purpose of this study is the complex retrospective analysis of the cases of rhinosinusal malignancies diagnosed and treated in the Otolaryngology Clinic of the St. Spiridon Emergency Clinical Hospital in lasi. We evaluated the characteristics of the patient group using a statistically significant analysis of the age, gender, background, and factors of affiliation. Specific tests and indicators have been used. It is not to be neglected the effects of the poor economic conditions andthe lack of education of the population, by postponing the moment of presentation tophysician, influencing the therapeutic decision, postoperative evolution. Thesepatients often present different degrees of malnutrition,immunodepression, etc. Statistical processing showed that thesepatients have a twofold risk of developing rhinosinusal tumours.
\end{abstract}

\section{Keywords: environmental risks factors, rhinosinusal cancers, nasal cavity}

Cancer of the nasal cavity and paranasal sinuses is quite rare. For example, in the UK the incidence is $8: 1,000,000$, while in the United States, where it represents $1 \%$ of all neoplasia, it has an incidence of 5:1,000,000. In both countries, the incidence rate for men:women is approximately equal, with the most common occurrence being in the second decade of life [1].

Although many studies give the maxillary sinus topography more frequent than the ethmoid sinus, it is hard to tell how such a conclusion has been reached as long as the clinical signs occurs only when the tumour reaches beyond the sinus. $80-100 \%$ of patients have radiologic signs of bone destruction.

The tumours of the nasal cavity are thus associated with the maxillary and ethmoidal sinuses. Those that start from the nasal vestibule and nasal septum raise particular problems and, although rare, form a particular group of cases among the rhinosinusal tumours. Cancers that invade only the inferior part of the jaw are better classified as cancers of the upper extension of buccal cavity [2-5].

Given that rhinosinusal neoplasia is not very common, it is difficult to identify favoring or determining factors. For example, smoking, the first favorable cause of other cancers of the respiratory tract, is not associated with rhinosinusal neoplasia [6-8].

Perhaps the best proven factor in the UK and France is working in the wood and coal industry. This was found by epidemiological studies with laboratory confirmation. People working in the wood industry have the same risk of developing an ethnoid adenocarcinoma as smokers to develop a broncho-pulmonary neoplasia. It seems to be a long latency associated with this factor (28-43 years) [913].
Radiation exposure, viral infections and constitutional factors were associated with the occurrence of rhinosinusal neoplasia also, but the evidence is inconclusive and indicates that only a small proportion of all squamous carcinomas can be attributed[14-18].

Nickel workers are at a risk of 870 times higher rhinosinusal tumours, most of them appearing after 10 years of exposure, but with improved working conditions, the incidence has fallen rapidly. The average latency period in these cases was 24 years. Patients who have worked in the chromium industry have a 21-fold higher risk of latency of 23 years[ 19,20$]$.

Non-occupational agents such as thorium dioxide injected into the maxillary sinus, exposure to hydrocarbons and isopropyl alcohol also increase the risk of rhinosinusal tumours. All of these injuries appear to develop as a result of nasal fossil air currents that trap and deposit irritating particles either at the anterior portion of the nasal septum or at the middle cornet, resulting in squamous metaplasia and then carcinoma [21-25]

The purpose of this study is the complex retrospective analysis of the cases of rhinosinusal malignancies diagnosed and treated in the Otolaryngology Clinic of the St. Spiridon Emergency Clinical Hospital in lasi between 1990 and 2004. We evaluated the characteristics of the patient group using a statistically significant analysis of the age, gender, background, and factors of affiliation. Specific tests and indicators have been used.

\section{Experimental part \\ Materials and methods}

We used a study group of 143 patients diagnosed with rhinosinusal malignant tumours in the oto-rhyno- *email: maria.domuta@yahoo.com.; mtusaliu@yahoo.com; mariusdabija.md@gmail.com
\#The authors contributed equally to this article and should be considered first author 
laryngology clinic of Sfantu Spiridon Hospital in lasi. These patients were monitored clinically, radiologically, paraclinicallyand anamnestically, in the pre-surgical period.

As methods, we used statistical series of dynamic variation of periods and dynamic momentum variation. For the square test, the x1 test is a nonparametric test used for statistical deductions in the case of two or more samples randomly drawn from a population and having a different frequency distribution betw een them.

This test compares two or more frequency distributions for tw o batches from the same population, so with a similar frequency distribution, butwith a differentfeature. Absolute figures are taken into account, thus making it more laborious to compute the average, the dispersion, the moments.

Also, this test applies only to those situations where the expected events exclude each other, in the sense that only one of them is possible.

For $\mathrm{df}=\mathrm{I}$ (degree of freedom) and a 95\% confidence we have Chi - square $\mathrm{X} 2=3.84$. If the calculated value is greater than this value means that there is association and the exposure has an influence on the studied disease.

Once the contingency table (or cross classification) is made, we calculated the odds ratio (CR) and the relative risk (RR) ratio.

\section{Results and discussions}

Chance report (CR) expresses the chances of those who are exposed to a certain feature are OR or higher than the odds of the unexplored ones.

The risk ratio (RR) expresses the risk of those exposed is RR or higher than those unexposed.

\section{Table 1}

PATIENTS DISTRIBUTION BY GENDER

\begin{tabular}{|c|c|c|}
\hline GENDER & NUMBER & PERCENT \\
\hline Female & 40 & $27.97 \%$ \\
\hline Male & 103 & $72.03 \%$ \\
\hline
\end{tabular}

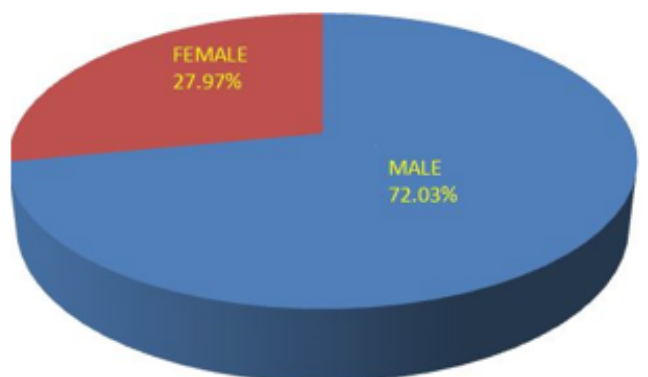

Fig. 1. Cases distribution by gender

The incidence of females cases was $27.97 \%$, small compared to the incidence of male cases.

Table 2

PATIENTS DISTRIBUTION BY DEMOGRAPHIC ORIGIN

\begin{tabular}{|c|c|c|}
\hline DEMOGRAPHIC ORIGIN & NUMBER & PERCENT \\
\hline Rural & 97 & $67.83 \%$ \\
\hline Urban & 46 & $33.17 \%$ \\
\hline
\end{tabular}

Achieving the contingency table allowed the study of patient involvement in the presence of TMRS.

A control group of patients (60 cases) without TMRS, randomly selected from the ENT Clinic, was used.

The very high values of Chi-square $(x 2=20.45)$ and the Spearman Rank correlation coefficient $(r=-0.74)$ lead to the conclusion that rhinosinus malignant tumors are
Table 3

PATIENTS DISTRIBUTION BY DEMOGRAPHIC ORIGIN AND TMRS
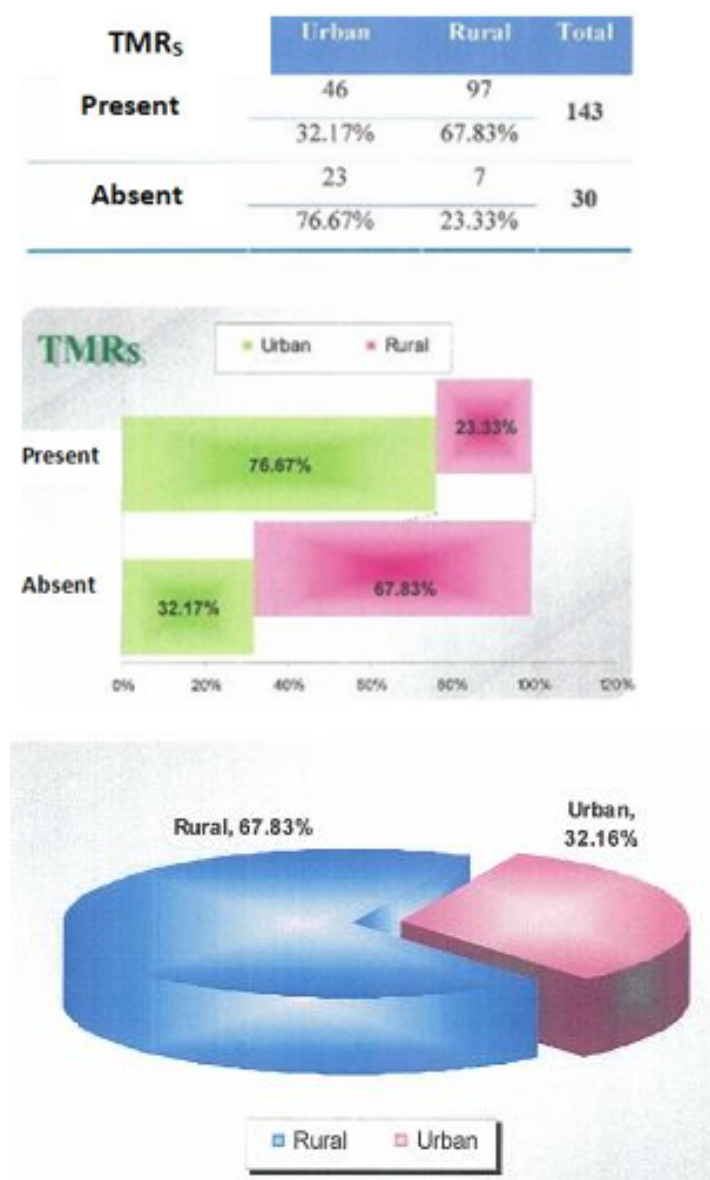

Fig. 2. The incidence of cases by the origin of the patients and TMRs significantly present in rural areas ( $p-0.000003,0.05)$, which also results from the analysis of the regression line (table 4, fig. 3).

Table 4

SQUARE-CHI TEST RESULTS

\begin{tabular}{|c|c|c|c|}
\hline $\begin{array}{c}\text { Demographic origin vs } \\
\text { TMR }\end{array}$ & $\begin{array}{c}\text { Chi-Square test } \\
\mathrm{X}^{2}\end{array}$ & df & $\mathrm{p}$ \\
\hline M-L-SQUARE-CHI Test & 20.45789 & 1 & 0.00001 \\
\hline Contingency coefficient & -0.592772 & & \\
\hline $\begin{array}{c}\text { Spearman Rank correlation } \\
\text { coefficient }\end{array}$ & -0.747748 & & 0.000003 \\
\hline
\end{tabular}

The slope of the regression line indicates the significant correlation between the patient's background and the presence of TMRS.

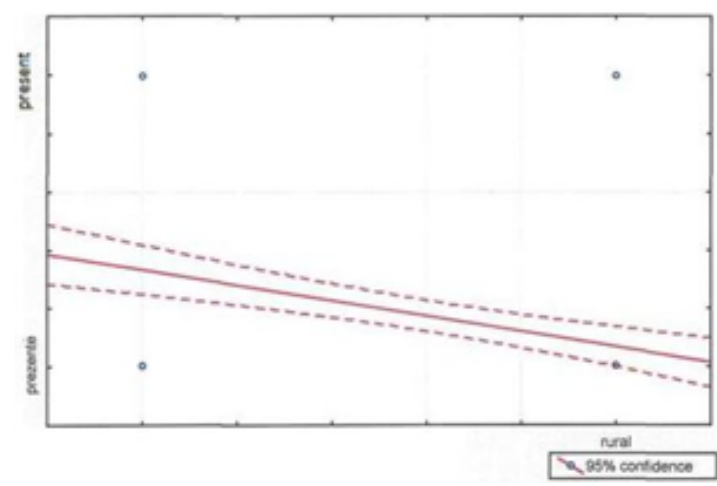

Fig. 3. Correlation of the demographic origin and the presence of rhinosinusal malignancies 
The histogram of the age of patients with rhinosinus malignancies reveals the normal distribution of cases by age (Gaussian distribution).

\section{Table 5}

DISTRIBUTION OF CASES BY AGE OF PATIENTS

\begin{tabular}{|l|l|l|}
\hline AGE & $\begin{array}{l}\text { NO. OF } \\
\text { CASES }\end{array}$ & \\
\hline$\leq 10$ & 3 & 2.1 \\
\hline $10 \leq A G E \leq 20$ & 6 & 4.2 \\
\hline $20 \leq A G E \leq 30$ & 12 & 8.39 \\
\hline $30 \leq A G E \leq 40$ & 18 & 12.59 \\
\hline $40 \leq A G E \leq 50$ & 26 & 18.18 \\
\hline $50 \leq A G E \leq 60$ & 30 & 20.98 \\
\hline
\end{tabular}

Major incidences of cases with rhinosinusal malignancies occur in patients aged $50-70$ years $(20.98 \%)$ (table 5, fig. 4).
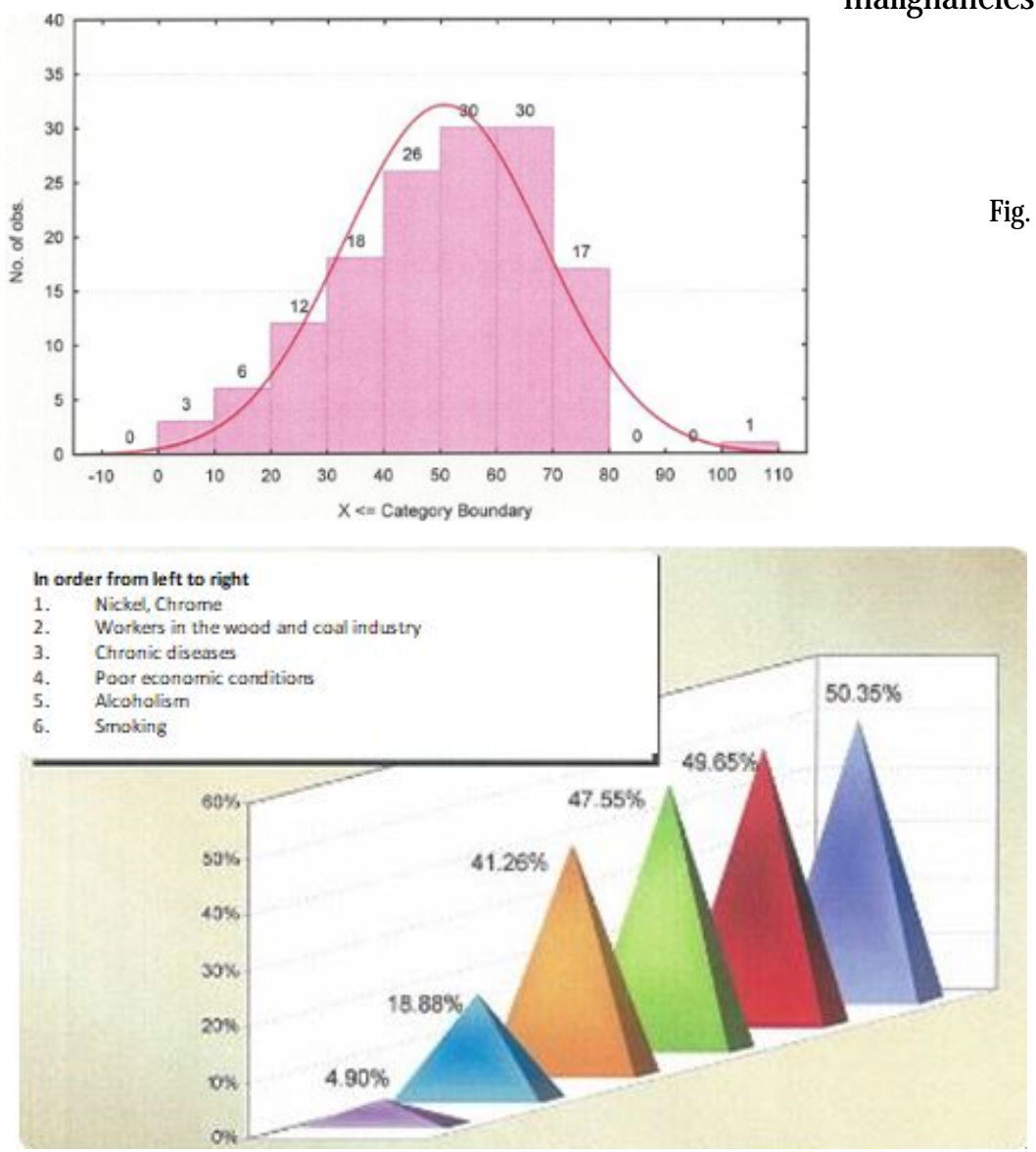

Table 6

THE INVOLVEMENT OF RISK FACTORS IN THE PRESENCE OF TUMORS

\begin{tabular}{|c|c|c|c|c|}
\hline $\begin{array}{c}\text { Predisposing factors involved in the etiopathogenesis } \\
\text { of malignant rhinosinusal tumours }\end{array}$ & $\begin{array}{c}\text { CR } \\
\text { Chance report }\end{array}$ & $\begin{array}{c}\text { RR } \\
\text { Risk Report }\end{array}$ & $\mathrm{X}^{2}$ & $\mathrm{p}$ \\
\hline Workers in the wood and coal industry & 5.28 & 2.47 & 14.07 & 0.0001763 \\
\hline Nickel, Chrome & 4.15 & 2.26 & 11.13 & 0.0008479 \\
\hline Chronic diseases (liver, diabetes, cardiovascular) & 3.21 & 2.02 & 7.29 & 0.0069444 \\
\hline Alcohol consumption & 2.71 & 1.86 & 5.28 & 0.0215787 \\
\hline Poor economic conditions & 2.49 & 1.78 & 4.37 & 0.0366590 \\
\hline Smoking & 2.37 & 1.68 & 4.12 & 0.0428729 \\
\hline
\end{tabular}

Fig 5. The incidence of risk factors in the the etiopathogenesis of malignant tumors of the hypopharynx 


\section{Conclusions}

We can not specify the existence of a determinant or favoring factor of the occurrence of rhinosinusal tumours but the statistical analysis noticed an ncreased risk for patients working in the wood industry(5.28), which are exposed to chromium, nickel (4.21) as well as to theassociated diseases (liver, cardiovascular, diabetes).It is not to be neglected the effects of the poor economic conditions andthe lack of education of the population, by postponing the moment of presentation tophysician, influencing the therapeutic decision, postoperative evolution. Thesepatients often present different degrees of malnutrition,immunodepression, etc. Statistical processing showed that thesepatients have a twofold risk of developing rhinosinusal tumours.

\section{References}

1.CARRAU RL, MYERS EN. Neoplasms of the Nose and Paranasal Sinuses. In Head and Neck Surgery-Otolaryngology by Bailey. 2nd ed. Lippincott-Raven Publishers. Pp 1445-1469.

2.MARAN AGD, LUND VL. Tumors of the nose and sinuses. Clinical Rhinology 1990: 140-177.

3.PALADE, D.O., COBZEANU, B.M., ZAHARIA, P., DABIJA, M., Rev.Chim. (Bucharest), 69, no.6, 2018, p. 1455-1457.

4.PALADE, D.O., COBZEANU, B.M., ZAHARIA, P., DABIJA, M., Rev. Chim.(Bucharest), 69, no.5, 2018, p. 1191-1193

5.COBZEANU, B.M., PALADE, D.O., DANCIU, M., NEGRU, D., COBZEANU, L.M., COBZEANU, M.D., Rev Med Chir Soc Nat lasi, 122, no.4, 2018, p.773777.

6.TATARINGA, G., STAN, C., MIRCEA, C., JITAREANU, A., ZBANCIOC, A.M.. Farmacia, 64, no.4, 2016, p. 533-538.

7.HINGANU, M.V., SALAHORU, P., HINGANU, D. Rev Med Chir Soc Med Nat lasi,122, no.3, 2018, p. 522.

8. BARBOI, OB, PRELIPCEAN, CC, COBZEANU, MD, PALADE, D, ALBUSODA, A, FLORIA, M, CHIRILA, I, DRUG, VL, BALAN, G. Rev Med Chir Soc Nat lasi, 119, no.4, 2015, p. 967-973. 3.

9.ACHESON, E.D., COWDELL, R.H. \& RANG, E.H. Nasal cancer in England and Wales: an occupational survey. $\mathrm{Br}$. J. ind. Med., 1981; 38, 218-224.

10.ANDREW K. Role of alcohol and tobacco in the etiology of head and neck cancer: acase-control study in the Doubs region of France. Eur J Cancer 1995; 31: 301.

11.BAXTER, P.)., MCDOWALL, M.E. Occupation and cancer in London: an investigation into nasal and bladder cancer using the Cancer Atlas. Br. J. ind. Med. 1986; 43, 44-49.

12.CECCHI, F., BUIATTI, E., KRIEBEL, D., NASTASI, L. \& SANTUCCI, M. Adenocarcinoma of the nose and paranasal sinuses in shoemakers and woodworkers in the province of Florence, Italy (1963-77). Br. J. ind. Med. 1980; 37, 222-225.

13.MANNETJE A, KOGEVINAS M et al: Sinonasal Cancer, Ocupation and Tobacco Smoking in European Women and Men. Ann J o. of Ind. Med 1999; 36: 101-107.
14.COBZEANU, MD, PALADE, D, MANEA, C. CHIRURGIA, 108, no.3, 2013, p. 360-364.

15.HINGANU, M.V., HINGANU, D., COZMA, S.R., ASIMIONOAIEISIMIONESCU, C., SCUTARIU, I.A., IONESIE, D.S., HABA, D. Annals of Anatomy, 220, 2018, p. 1.

16.ROUSH G.C. Cancer of nasal cavity and paranasal sinuses. In: Cancer epidemiology and prevention, second ed. 1996, New York : Oxford University Press. p.587-602.

17.BIMBI G, SARACENO MS, RICCIO S, GATTA G, LICITRA L, CANTU G. Adenocarcinoma of ethmoid sinus: An occupational disease. Acta Otorhinolaryngol Ital 2004;24:199-203

18.TOMA, A.G., SALAHORU P., HINGANU, M.V., HINGANU, D., DIMA COZMA, L. L., PATRASCU, A., GRIGORESCU C. Rev.Chim.(Bucharest), 70, no.1, 2019, p. 143.

19.BARTON RT. Nickel carcinogenesis of the respiratory tract. J. Otolaryngol. 1977; 6:412.

20.BATTISTA, G., CAVALLUCCI, F., COMBA, P., QUERCIA, A., VINDIGNI, C. \& SARTORELLI, E. A case-referent study on nasal cancer and exposure to wood dust in the province of Sienna, Italy. Scand. J. Work Environ 1983; Health, 9, 25-29.

21.BIRT BD, BRIANT TDR. Otolaryngol ClinNorth Ann 1976; 9: 249.

22.ELW OOD, J.M. Can. med. Assoc. J.,1981; 124,1573-1577.

23.HINGANU M.V., COZMA R.S., CIOCHINA P., SCUTARIU I.A., ASIMIONOAIEI-SIMIONESCU C., HINGANU D.Rom J Morphol Embryol 58, 2017, no.4, p. 1365.

24.ESPING, B., AXELSON, 0. SCAND. J. Work Environ. Health, 1980; 6, 201-205

25.HINGANU MV, STAN Cl, TAARANU T, HîNGANU D. Rom J Morphol Embryol 58, no.3, 2017, p. 851-855.

26.LOSTUN, G., LOSTUN, A., HAINAROSIE, R., et al. Rev. Chim.(Bucharest), 67, no.6, 2016, p. 1183-1185.

27.CUCIUREANU, D.I., STATESCU, C., SASCAU,R.A.,,et al. Rev.Chim. (Bucharest), 70, no.2, 2019, p.685-688.

28.ACHESON, E.D., COWDELL, R.H. \& RANG, E.H. Br. J. ind. Med $1981 ; 38,218-224$

29.HINGANU, D., STAN, C.I., TARANU, T., HINGANU, M.V. Rom J Morphol Embryol, 58, no.4, 2017, p.1327.

30.ANDREW K. Eur J Cancer 1995; 31: 301.

31.URSU, RG, IVANOV, I, POPESCU, E, COSTAN, V, STAMATIN, 0, GHETU, N, PALADE, D, MARTU, C, ANDRESE, E et al. Rev Med Chir Soc Nat lasi, 119, no.3, 2015, p. 676-680.

32.MACOVEI, L.A., CRISTESCU, V., DEBITA, M., et al. Rev.Chim.(Bucharest), 68, no. 10, 2017, p. 2440-2442.

33.LECA, D.,CALIN, A.,M., EARAR, K., NECHITA, A., CHISCOP, I., DOROBAT, G., DOROBAT, C., ILIE, M., DEBITA, M., Rev.Chim. (Bucharest), 66, no.12, 2015, p.2005-2008.

34.GAVRILOVICI, C, LUCA, A, ANTONIU, SA, GALLABY, K, STEFANESCU, R ,STARCEA, M, MIRON, I, BILD, V. Farmacia, 66, 2018, no. 2, p. 197208.

Manuscript received:9.09.2018 